\title{
Guidance and Recommendations for Sustainable Management of a Construction Project
}

\author{
Prof. Naheed B Mir Mumtaz Ali* \\ *Department of Architecture, Jawaharlal Nehru Engineering College, Mahatma Gandhi Mission University \\ Aurangabad, Maharashtra, India
}

\begin{abstract}
Sustainability in construction helps to minimize the consequences of material, Social and pollution factor and stakeholders on the construction site. It also helps to prepare the strategies and methods to follow throughout the given timeline of the project. The Sustainable construction management plan (SCMP) also aid to define the potential amenity disturbance during construction with allusion to project scale. SCMP of any project characterized on the following four main phases: Achieving Sustainable parameters through Architectural design of the building; Material selection and its impact factors on built environment; Type of Project (New/Refurbishment/Demolition) and on-site measurements accordingly; Sustainable delivery action. Nevertheless, the sustainable construction and building materials, both combinations used in the common planning procedure for handling the construction on site in order to reduce the waste and environmental impact with the sophisticated methodologies. Establishing the well manageable goals, re-organizing the building layout (in refurbishment case), thermal comfort, cost management and minimization, minimum environmental impact on site and surroundings are immense challenges faced while preparing and acting the SCMP on construction site. This research paper will help to understand the construction management plan guidelines and recommendations of the construction site where the condition of refurbishment considered and Sustainability as a primary objective.
\end{abstract}

Keywords:- Management Plan, Construction, Sustainability, Factors, Guidelines, Recommendations.

\section{INTRODUCTION}

The Word "Sustainable Development" defined as "Development that meets the needs of the present without compromising the ability of future generations to meet their own needs" (Brundtland Commission, 1987). Achieving the Sustainability in construction management of any site will be the major concern for an Architect, Project manager and Developer of the Project. Further study of this research paper will help to analyze the Sustainable Construction management plan in detail.

\section{SUSTAINABLE CONSTRUCTION}

It has been observed that construction sector was always a resource of depletion of the Global economy. Still few countries are struggling with managing the construction and its impact on the surrounding Environment. This approach has given chance to adopt the sustainability as a key concept and also introduced the Building assessment methods such as BREEAM in United Kingdom, SAGRS in Kingdom of Saudi Arabia, LEED in United State of America, GRIHA in India, GREEN STAR in Australia and SBTool in collaborative. To achieve the targets and handling the Environment issues strategic plan and Action plan has to prepare on the bases of three Principles of Sustainability which are: Planet, People and Prosperity.

PLANET

Possibly reducing the impact of environmental factors of project.

PEOPLE Planning and delivering - Including construction mode of the project and behavioural aspects, offer comfortable access to everyone.

PROSPERITY

Presenting and developing economic development of the city on the sustainable manner.

Fig 1:- 3 Principles of Sustainability

\section{Sustainable Construction Management Plan (SCMP):}

To designate the responsibilities and safety measures, the Construction management plan has to prepare and implement on the site. where the Sustainability will be the major key to handle the Refurbishment project in a most cost-effective way and also considering the Time factor, site surrounding and Environment throughout the construction frame and later to accomplish the Excellent assessment rating. 


\section{Targets of the SCMP:}

Setting up the targets for SCMP will be a strenuous task. Before targeting the management plan, the factors affecting to the project has to identify. The factors can be site environment and its surroundings, Pollution control, enhancing the social fraternity, taking care of existing Biodiversity, recycling and reuse of materials and managing the design and construction process to achieve the targets with in the built-environment.

\section{$>$ Key Consideration to Achieve SCMP:}

The management plan is an aid to identify, design, target, action and maintenance on-site considering the sustainability as a primary objective. Following process implement to achieve the sustainability in Design stage and as well in construction phase:

- Identifying the type of project (Refurbishment versus Demolition) and associated issues within the site.

- Developing the Architectural/Interior Design brief and preparing the project budget on bases developed objectives.

- Sustainable Design strategies and implementations while construction and after completion of the project considering the building assessment rating criteria's (National and International level)

- Taking care of sustainability measures on-site while construction such as foot prints of $\mathrm{CO} 2$ emission, Waste, Noise, Light and other aspects.

- Availability of materials, services and on-site behaviour.

- Action plan for proper administration and allot the responsibilities to follow on-site throughout the construction of project maintaining sustainability.

\section{SELECTED CASE-STUDY REVIEW}

Type of Case-study: Refurbishment

Name of case-study: University of Brighton, Cockcroft campus, Moulsecoomb, South-Coast of England, United Kingdom

Overview: The traditional cycle of any building typically constructs with a span of 40-60 years or more than 60 years depend on the internal and external demand of the working environment of the building. Based on demand and supply criteria of any building goes under refurbishment process, where the scale, type and level of project will differ. In the refurbishment process not only design of services and the energy demand and supply will change but also following challenges will also delivered on the bases of sustainable development such as climate change, impact on internal and external environment and provision of secure and safety internal environment in the upgrade of services. In the refurbishment process sustainable development and construction plays a larger role to control the hazards on site and also contribute to low carbon emission and climate change aspects. It also protects the current and future built environment in the project. This research paper trying to focus on the recommendation on sustainable energy systems suitable for selected project and also helps to analyse the
Policy and Guidelines prepared by the UK government when any Building going under Refurbishment state. The proposed project located in Brighton city, United Kingdom and known as one of the leading educational hubs in England, UK. The building comprises on 15,000sq.m gross floor space with supporting facility such as laboratories, administrative office, cafes and lecture halls with the 1520 occupants.

\section{GUIDANCE \& RECOMMENDATIONS}

\section{* Construction Management Plan(CMP)}

Guidance: it is advised by the UK Government in legislation and regulations that for any construction site, Management plan has to prepare as it is important to characterize the significance of the project and also strategies the Transportation management, Waste \& Pollution management and water usage, etc. on-site. It is further advised by the higher authorities to follow the Design \& Management 2007 and approved Code of Practice while preparing.

\section{$>$ Recommendations:}

- The profile of the CMP provides the overview of factors and procedures to implement in the Design and Construction stage, where as the type of project such as New build, Demolition and Refurbishment are contemplate.

- Health and Safety will be the main aspect to consider in CMP where sustainability is the primary object.

- As the selected case-study is an Educational hub and going under Refurbishment process while few floors occupied by the people, the CMP should focus on the role and responsibilities of the administration and management individuals. Where as the traffic routes, time-table of demolition and refurbishment, security, Environment, fire safety, water usage for the workers and occupants has to work out on the bases of Sustainability notion.

- The CMP also outline the role and responsibilities of a Client, Architect, Principal contractor and subcontractors, occupants and workers towards the project.

\section{* Resource Management}

\section{A. Energy \& CO2 Emission}

Guidance: with reference to the Government construction strategy (May 2011), the guidelines for action plan given to strategies the movement and environmental impact on the site.

\section{Recommendations:}

- Taking practicable measures on site to control the energy consumption and the $\mathrm{CO} 2$ emission (Electricity, Petrol or Gas).

- Raising sensitivity in the inhabitants towards the rules and induction on-site environment and usage of the energy.

- The management of the $\mathrm{CO} 2$ emission should be outlined under the Action plan baselines 2008. 
- Taking care of vehicle movement (Material delivery and waste removal) $(90 \% \quad \mathrm{CO} 2$ emission $)$, site accommodation and Business travels $(15 \%$ CO2 emission), Refurbishment \& maintenance (36\% CO2 emission).

\section{B. Material \& Waste}

Guidance: Incorporating the rules and strategies from Sustainable construction 2008 and Health Technical Memorandum 07-01 'Safe management of Healthcare waste'. The document focus on the waste hierarchy procuring through best practices, concept of reusing and recycling of materials, minimization and eliminate the use of new materials.

\section{$>$ Recommendations:}

- The scrap and new material storage location have to identify on-site. Also, the location for disposable of scrap. These two locations have to identify in the design proposal.

- Distinguish between recycling material and waste from the demolish. This process helps to clear the waste generation and reduce the amount of material to be sent to the disposable site.

- The materials such as paint, oil, grease, etc. have to handle very carefully and responsibility has to give to the licensed company in the market.

- Calculating the waste generation on-site and sending to the disposable site regularly to maintain the site Environment and surroundings.

\section{Waste management Plan}

Guidance: Considering the site condition, waste material generated during refurbishment verses usage of vehicle movement on site to remove waste and other factors has to calculate. For this local authorities and regional level policy documents has to review. For this selected case Brighton \& Hove Structure Plan, the East Sussex and Brighton \& Hove Waste Local Plan, Planning Policy Statement 10 - Planning for Sustainable Waste Management proposed.

\section{$>$ Recommendations:}

- Under the waste management plan few aspects has to consider such as: the waste material generated through site refurbishment, recycling process, categorization of material for reuse and recovery, usage of new material and its storage control on-site and material to be sent to the disposal site will be the major concern.

- To control the behaviour of site through efficient design strategies, storage locations, waste material collection and construction techniques has to outlines in this management plan.

- The proposal to the material salvage will plan under waste management plan. The salvage will rbe characterized and will take action accordingly.

\section{* Pollution Management Plan \\ A. Indoor Air Quality (IAQ) (Air \& Dust Pollution)}

Guidance: achieving the IAQ and pollution control on site will be a demanding task especially when the site is under going refurbishment and demolition procedure. The guidance to refer are Control of Pollution Act 1974 Part IV; the Health and Safety at Work Act 1974, the Clean Air Act 1993 and the Environmental Protection Act 1990.

\section{$>$ Recommendations:}

- Using Extraction systems on site to improve the air and dust control on-site for better environment.

- Raising awareness in the workers and occupants of the site about IAQ and guidelines to follow.

- It is also advisable to instruct the workers about the precautions to take while working and should strictly follow the code of practices for demolition (BS 6187:2000 Code of Practice for Demolition).

\section{B. Noise and Light Pollution}

Guidance: For Noise and Light pollution control onsite should take the references from local environmental quality guidance (Section 69 to 81 and 86, 101 and 103) of the Clean Neighborhoods and Environmental Act and Control of Noise at Work Regulations 2005. Also focusing on Environmental assessment plan and protection plan (2004 and 1995) will be helpful.

\section{$>$ Recommendations:}

- Proposed mitigation measures will take on site further.

- Controlling the activities on site during the day time and in business hours (Local authority schedule time).

- Minimizing the use of artificial lighting during refurbishment on-site.

- Few aspects such as duration of work, impact of Noise and light pollution on local environment, etc should take care while construction is in progress.

\section{Water Usage}

Guidance: to supply the demand of the occupants and misuse of the water on-site, 07-04 Water management and Efficiency and Water Regulation Advisory Scheme (WRAS) has to implement. Also, the listed Water Fittings and Materials Directory (WRAS, 2006) will be used in construction to avoid wastage and contamination.

\section{$>$ Recommendations:}

- Supply of the water will depend on the per day consumption of water verses number of working days of workers and occupants on the site.

- Cleanliness, management and efficiency of water will be proceeding with the rules and regulations.

- Rain water harvesting and Grey water usage

- Temporary toilets and Admin office location has to mark on Design report. Accordingly, the sewer line for the same will take care. 


\section{Site water Run-Off}

Guidance: The Defra (Department for Environment, Food and Rural Affairs) of UK, provide the guidance and regulations at Design stage and construction phase for the site water run-off.

\section{$>$ Recommendations:}

The profile of the site construction is in internal phase refurbishment of the Cockcroft campus. How ever the chances of water run-off will be negligible manner and it will be connected to the local sewer line.

\section{* Transport Management}

\section{A. Local \& Urban Transportation}

Guidance: Preparing the traffic management plan under the Local planning policy guidelines-13 of Brighton $\&$ Hove council. Also consider the health and safety measures.

\section{$>$ Recommendations:}

- The refurbishment procedure is in intenral facade of the building, so the awarness signs and instructions has to displayed at the entrance and wher ever necessary.

- Encourage everyone to use the local transportation as it will decrease the pollution and $\mathrm{CO} 2$ emission on site.

- Displaying the road networks and Vehicle movement plan to improve the access to the site.

- Traffic management and development has to prepare with the Design report.

\section{* Social Factors}

A. Employment Avenues

Guidance: The key aim of Construction Design and management, 2007 is to integrate health and safety into the management of the project and to encourage everyone involved to work together. According to the CMD Regulations (2007) adopted to characterize the employees on site construction. It also helps to define the role and responsibility of every appointed person on site.

\section{$>$ Recommendations:}

- Identifying the employment hierarchy and suitable positions of the work accordingly (Skilled and unskilled workers).

- Providing the training to the staff before the construction work start to follow the concept of Sustainability.

- Maintaining the healthy environment on-site and taking care of safety.

\section{B. Community Involvement}

Guidance: Identifying the responsibilities and involvement of the community and shareholders of the site voluntarily to work constructively and achieve the Goals, targets set out in the Design report conceding sustainability as a primary concern. In this procedure the National Strategic Partnership Forums (2007) helps to focus on the objectives to involve the community to create healthy environment.

\section{Recommendations:}

- Identifying the local community, neighborhood, worker's profile and their necessities.

- Allowing the community to take active participation in Design and construction stage to create healthy and better environment.

\section{REFERENCES}

[1]. Appleby, P (2011). UK Low Carbon Construction Action Plan: The Government's Response to the IGT Report (9 July 2011, online). Paul Appleby Sustainability Consultant, http://paulapplebysblog.blogspot.co.uk/2011/07. Accessed 20 January 2014.

[2]. Building Research Establishment (2013). Green Guide to Specification (2013, online). BRE Global, http://www.bre.co.uk/greenguide/podpage.jsp?id=212 6. Accessed 16 January 2014.

[3]. Communities and Local Government (2006). Codes for Sustainable Homes (online). http://www.planningportal.gov.uk/uploads/code_for_s ust_homes.pdf Accessed 10 January 2014.

[4]. Communities and Local Government Select Committee (2011). National Planning Policy Framework: Written evidence from BRE Global (19 August 2011, online). UK Parliament, http://www.publications.parliament.uk/pa/cm201012/c mselect/cmcomloc/writev/nppf/nppf03.htm. Accessed 11 January 2014

[5]. Department for Environment, food and Rural Affairs (2013). Local Environment Quality (updated 09 April 2013, online.) https://www.gov.uk/localenvironmental-quality. Accessed 17 January 2014.

[6]. Department of Health (2007). National Strategic Partnership Forum (NSPF) (online) http://webarchive.nationalarchives.gov.uk/+/www.dh. gov.uk/en/AboutUs/DeliveringHealthAndSocialCare/ OrganisationsThatWorkWithDH/WorkingWithStakeh olders/DH_4116814. Accessed 20 January 2014.

[7]. Department for Environment, Food and Rural affairs (2011) (online) https://www.gov.uk/government/uploads/system/uplo ads/attachment_data/file/82421/suds-consult-annexanational-standards-111221.pdf. Accessed 05 January 2014.

[8]. Defra (2009), Guidance on how to measure and report your greenhouse gas emissions,

[9]. Available at http://www.defra.gov.uk/environment/business/reporti ng/index.htm. Accessed 16 January 2014

[10]. Legislation.gov.uk. (2007). The Construction (Design and Management) Regulations 2007 (online) http://www.legislation.gov.uk/uksi/2007/320/contents/ made. Accessed 12 January 2014

[11]. Health and Safety Executive. (2007) The Approved Code of Practice (ACOP) (online) http://www.hse.gov.uk/construction/cdm/acop.htm. Accessed 20 January 2014. 
[12]. Supplementary Planning Document. (2006). Construction and Demolition of Waste (online) http://www.brighton-hove.gov.uk/sites/brightonhove.gov.uk/files/downloads/planning_strategy/SWM $\mathrm{P}$ -

Construction_Demolition_Waste_SPD_March_2006.p df. Accessed 15 January 2014.

[13]. WRAP (2008). Guidelines for measuring and reporting construction, demolition and excavation waste.

(online) http://reportingportal.wrap.org.uk/Downloads/CDEW \%20Reporting\%20Guidance.pdf. Accessed 20 January 2014.

[14]. Environmental Agency. Environmental good practice guide for ground source heating and cooling. (online).

[15].http://www.gshp.org.uk/pdf/ea_gshc_good_practice_g uide.pdf. Accessed 20 January 2014 